\title{
Education Management Cyber Defense at The University School of Ministry of Defense of the Office Republic Indonesia in The Area Corona Virus Pandemic (Covid 19)
}

\author{
Dian Damayanti \\ Institut Ilmu social and manajemen Stiami Indonesia
}

\begin{abstract}
Cyber education Management at the Defense University school of ministry of defense of the office republic Indonesia in the area pandemic corona virus (covid19). Law No. 20 of 2003 concerning the National Education System (Sisdiknas) which states that the state realizes the right of the people to get quality and free 9 (nine) years of basic education by supporting efforts to develop alternative education, especially for areas affected by disasters, remote areas, as well as for groups with special needs (Depdiknas, 2003).
\end{abstract}

This study uses a qualitative method. Based on the results of research and discussions regarding cyber education Management policy at the Defense University of the republic Indonesia in the area pandemic corona virus (covid19). The government and various parties have carried out an emergency response including by holding emergency schools for student university defense in the event of the corona virus pandemic. The psychological burden that hit children throughout Indonesia during the Covid-19 pandemic resulted in decreased motivation to learn. This condition requires special handling in order to create joyful learning activities. One form of special handling that is the focus of research and which will be discussed in this paper is learning activities that utilize electronic media. Produce graduates who are professional, innovative, civil-military leaders who have values of struggle and struggle that are able to synergize people's welfare needs with the interests of defense and state defense. Produce and contribute new knowledge in the fields of defense policy, management, strategy and technology both at the national and international levels.

Produce works of empirical knowledge, theories, concepts, methodologies, models, the latest work systems and defense capacity in the framework of the management of the national defense system. Produce a system of management and education administration according to quality standards, transparent, performance-based and the development of an academic culture. Generating benefits from partnerships and networks with various domestic and 
foreign agencies in supporting the Tridharma of Higher Education. The establishment of professional and competitive human resources (lecturers and educational staff) in the field of national defense and defense. The availability of educational facilities and infrastructure to support innovative and modern learning.

Keywords: Cyber Education, Management, Policy, Defense, Pandemic, Corona Virus professional, innovative, civil-military

\section{Introduction}

The spread of Covid-19 in recent weeks includes those in 216 countries. Based on data on the distribution of cases up to September 9, 2020, the number of positive cases was 27 486960 with a death rate of 894983 . In Indonesia, based on data on the distribution of cases up to September 13, 2020, the number of positive cases was 218,382 , the death rate was 8,723 , and 155,010 recovered spread across 34 provinces and 490 municipalities in Indonesia. 32 deaths / 1 million population in Indonesia. The total number of students at Defense University of the republic Indonesia is 664 people. consisting of 300 undergraduate students, 300 master students, and 64 doctoral students.

\section{THEORIES}

\section{A. Cyber education Management}

Law No. 20 of 2003 concerning the National Education System (Sisdiknas) which states that the state realizes the right of the people to get quality and free 9 (nine) years of basic education by supporting efforts to develop alternative education, especially for areas affected by disasters, remote areas, as well as for groups with special needs (Depdiknas, 2003).

Psychologically, the impact of natural disasters can be according to Daryanto resulting in spiritual exhaustion of children. Then, spiritual fatigue is one of the factors that affect children's learning activities (Daryanto, 2010). Noting this situation, the Ministry of Education has established regulations for setting guidelines for implementing the kirikulum in educational units in special conditions of the corona virus pandemic.

Learning is a complex process that occurs in everyone throughout his life. The learning process occurs because of the interaction between a person and their environment. Therefore, learning can occur anytime and anywhere (Arsyad, 2009). According to Bell-Gredler in Udin S. Winataputra (Winataputra, 2008), the notion of learning is a process carried out by humans to acquire various competencies, skills, and attitudes gradually and continuously starting from infancy. until old age through a series of lifelong learning processes. (http://techonly13.wordpress.com accessed on 14 September 2020 at 14.00 WIB). The use of instructional media is one of the alternative solutions to overcome the difficulties / limitations of implementing learning activities because one of the main functions of learning media is as a teaching aid which influences the conditions and learning environment that are organized and created by teachers (Arsyad, 2009). It is further stated that the use of the media learning in the teaching-learning process can generate new desires and interests, generate motivation 
and stimulation of learning activities, and even bring psychological effects on students. Closely related to the use of this learning media, Suedi Ahmad stated that the practical values of the use of media (http://www.slideshare.net accessed on 14 September 2020 at 14.00 WIB), namely: Visualizing abstract (example: animation of blood circulation), Bring objects that are hard to find (for example: wild / dangerous animals), $\bullet$ carrying objects that are too large (for example: mountain, market), - display objects that cannot be observed eye (example: micro organism), $\bullet$ watch for movements that are too fast (example: the course of the bullet), $\bullet$ allows interacting with the environment, $\bullet$ allows uniformity of experience, $\bullet$ reduce the risk if the object is dangerous. - presents consistent information and it is possible to be repeated according to needs, - generate motivation to learn, $\cdot$ can be presented in an interesting and varied, • control the direction and speed of learning learners, $\bullet$ presents learning information synchronously and can be repeated as well stored according to need, or • overcome the limitations of space and time. Furthermore, the definition of media literally is the plural of médium. Media according to Arief S. Sadiman, et al. is an intermediary or an introduction (Sadiman, et al., 2007). More understanding complete again is that stated by Robert Heinich is the intermediary deliver information between sources and recipient (Heinich, 2002). Then, Latuhelu suggested that which was intended with the media are all forms of intermediary used by humans for convey or disseminate ideas, ideas, or opinions thus ideas, ideas or opinions expressed up to to the intended recipient (Latuhelu, 1993). Still about the meaning of the media, opinions Leslie J. Briggs referred to by Arief S. Sadiman, et al. Said that the media is all physical means that can be presenting messages and stimulating participants students to learn (Sadiman, et al., 2007). It appears that whatever the limit, on in principle, the media is an intermediary used by humans to convey messages from sender to receiver and vice versa. If the media carries messages or information that contains learning material, then the media is referred to as media learning (Heinich, et al., 1982). One form or type of media learning is Video Compack Disk (VCD). The definition of VCD according to Darmawan as referred to by Iswahyudi in Murtini is an information storage system images and sounds (Murtini, 2010) and motion. Physically the Video / VCD learning is a learning program that is packaged in video cassette or VCD and presented with using a VTR device or a VCD player as well as TV monitors. (http://vcdpembelajaran.com accessed on 14 September 2020 at $14.00 \mathrm{WIB}$ ). Therefore, the media used to present the material learning (from teachers, tutors / facilitators, or other resource persons to students) who packaged in such a way as to stimulate / motivate students to learn.

According to Malayu S.P Hasibuan (2016: 1), management comes from the word to manage means to regulate. What is regulated, what is the goal set, why should it be regulated, who is it set up, and how to set it up.

What is regulated are all elements of management, namely $6 \mathrm{M}$. The objective is set to make $6 \mathrm{M}$ more efficient and effective in realizing the goal. It must be regulated so that the $6 \mathrm{M}$ is optimally beneficial, coordinated and integrated with good in supporting the realization of organizational goals. What regulates is the leadership with the leadership, namely the top leadership middle manager, and supervision. To organize it is to carry out activities sequencing the management function. 
Management is a process to achieve the desired goals. Management as a science, management is also universal and using a systematic scientific framework. Management science can be applied in all human organizations, companies, government, education, social, religious and others.

\section{B. Pandemic Corona Virus (covid - 19)}

Pandemic (from Greek $\pi \tilde{\alpha} v$, pan, "all" and $\delta \tilde{\eta} \mu \rho \varsigma$, demos, "people") is an epidemic of an infectious disease that has spread across a large region, for instance multiple continents or worldwide, affecting a substantial number of people. A widespread endemic disease with a stable number of infected people is not a pandemic. Widespread endemic diseases with a stable number of infected people such as recurrences of seasonal influenza are generally excluded as they occur simultaneously in large regions of the globe rather than being spread worldwide. Throughout human history, there have been a number of pandemics of diseases such as smallpox and tuberculosis. The most fatal pandemic in recorded history was the Black Death (also known as The Plague), which killed an estimated 75-200 million people in the 14th century (Gould 1966, p. 617).

Corona viruses are a group of related RNA viruses that cause diseases in mammals and birds. In humans, these viruses cause respiratory tract infections that can range from mild to lethal. Mild illnesses include some cases of the common cold (which is also caused by other viruses, predominantly rhinoviruses), while more lethal varieties can cause $\underline{\text { SARS, MERS, }}$ and COVID-19. They are divided into alpha corona viruses and beta coronaviruses which infect mammals - and gamma corona viruses and delta corona viruses, which primarily infect birds.

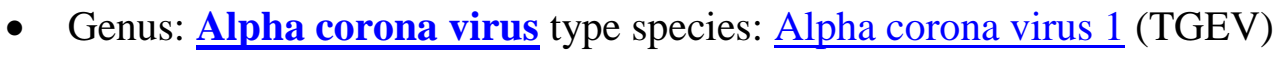

Species: Alpha corona virus 1, Human coronavirus 229E, Human coronavirus NL63, Mini opterus bat coronavirus 1 , Mini opterus bat coronavirus HKU8, Porcine epidemic diarrhea virus, Rhinolophus bat coronavirus HKU2, Scotophilus bat coronavirus 512

- Genus Beta corona virus type species: Murine corona virus (MHV)

Species: Beta corona virus 1 (Bovine Coronavirus, Human coronavirus OC43), Hedgehog coronavirus 1, Human coronavirus HKU1, Middle East respiratory syndrome-related coronavirus, Murine coronavirus, Pipistrellus bat coronavirus HKU5, Rousettus bat coronavirus HKU9, Severe acute respiratory syndrome-related coronavirus (SARS-CoV, SARS-CoV-2), Tylonycteris bat coronavirus HKU4

- Genus Gamma corona virus type species: Avian coronavirus (IBV) Species: Avian coronavirus, Beluga whale coronavirus SW1

- Genus Delta corona virus; type species: Bulbul coronavirus HKU11 Species:

Bulbul corona virus HKU11, Porcine corona virus HKU15 (McIntosh K, 1974). 


\section{SIENAEDUCATION}

02-04 JULY, 2021

Oxford, United Kingdom

\section{Methodology}

Qualitative research is a means for exploring and understanding the meaning individuals or groups ascribe to a social or human problem. The process of research involves emerging questions and procedures. Data typically collected in the participant's setting. data analysis inductively building from particulars to general themes. and the researcher making interpretations of the meaning of the data. The final written report has a flexible structure. Those who engage in this form of inquiry support a way of looking at research that honors an inductive style, a focus on individual meaning. and the importance of rendering the complexity of a situation (Creswell. 2013).

\section{A. Informant}

1. Staff academic at the Defense University of the republic Indonesia

2. lecturer at the Defense University of the republic Indonesia

\section{RESEARCH RESULTS, AND RESEARCH DISCUSSION}

\section{Cyber education Management policy at the Defense University of the republic Indonesia in the area pandemic corona virus (covid19).}

Cyber education Management at the Defense University of the republic Indonesia in the area pandemic corona virus (covid19). Law No. 20 of 2003 concerning the National Education System (Sisdiknas) which states that the state realizes the right of the people to get quality and free 9 (nine) years of basic education by supporting efforts to develop alternative education, especially for areas affected by disasters, remote areas, as well as for groups with special needs (Depdiknas, 2003).

Cyber education Management at the Defense University of the republic Indonesia in the area pandemic corona virus (covid19). also often do not have a clear understanding of the various instruments available to them. Policy is an intention, a product of the creative human imagination. Policy-making can be done in a more or less inventive way: deliberately engaging in brainstorming and free association, rather than rummaging through to see what "problem-solving solutions" are at the bottom of the existing "trash can" in universe policy using theory (Olsen 1972a; March 1976; March and Olsen 1976).

But even though they are creative, the makers Cyber education Management at the Defense University of the republic Indonesia in the area pandemic corona virus (covid19) will always thwart high modernist ambitions to a greater or lesser degree because of their limited knowledge. About all possible means of achieving the objectives in the policy. Perhaps most surprising of all, the makers Cyber education Management at the Defense University of the republic Indonesia in the area pandemic corona virus (covid19). failed in their "high modernist" ambition of perfect instrumental rationality because they did not even 
have the right idea. clear and well-established about the goals (values, objectives) of the policy. Many things are certain to be part of the background which is taken for granted in all deliberate action. It may never have occurred to us to determine that we value some of the results we always enjoy until some new policy intervention suddenly threatens them: wildlife and species diversity, or climate, or stable families, or whatever. We often don't know what we want until we see what we get, not because our preferences are irrationally adaptive (or perhaps counter-adaptive) but simply because our ability to imagine and catalog all the good is itself very limited. The limitation of instrumental rationality strengthens the cases made in this chapter for the study Cyber education Management policy at the Defense University of the republic Indonesia in the area pandemic corona virus (covid19). As persuasive calls, because they reinforce the case that policy is best made, and developed, as a kind of selfdiscovery journey, in which we have the experience of learning what we really want. And what we learn to want is partly a product of what we already have and know - that is, some of it is a product Cyber education Management policy at the Defense University of the republic Indonesia in the area pandemic corona virus (covid19). which has we made before. Acknowledging the limits of instrumental rationality also strengthens the case for selfconscious eclecticism in the choice of "means of government". These "tools" are social technologies and as such their use and effectiveness are highly dependent on the settings in which they are used. That arrangement is also in part a product of what has happened before. In other words, policy legacy is a key factor in policy choice.

Based on the results of research and discussions regarding cyber education Management policy at the Defense University of the republic Indonesia in the area pandemic corona virus (covid19). The government and various parties have carried out an emergency response including by holding emergency schools for student university defense in the event of the corona virus pandemic. The psychological burden that hit children throughout Indonesia during the Covid-19 pandemic resulted in decreased motivation to learn. This condition requires special handling in order to create joyful learning activities. One form of special handling that is the focus of research and which will be discussed in this paper is learning activities that utilize electronic media. Produce graduates who are professional, innovative, civil-military leaders who have values of struggle and struggle that are able to synergize people's welfare needs with the interests of defense and state defense. Produce and contribute new knowledge in the fields of defense policy, management, strategy and technology both at the national and international levels.

Produce works of empirical knowledge, theories, concepts, methodologies, models, the latest work systems and defense capacity in the framework of the management of the national defense system. Produce a system of management and education administration according to quality standards, transparent, performance-based and the development of an academic culture. Generating benefits from partnerships and networks with various domestic and 
foreign agencies in supporting the Tridharma of Higher Education. The establishment of professional and competitive human resources (lecturers and educational staff) in the field of national defense and defense. The availability of educational facilities and infrastructure to support innovative and modern learning.

\section{What obstacles have been faced in Cyber education Management at the Defense University of the republic Indonesia in the area pandemic corona virus (covid19)?}

barriers to cyber education Management at the Defense University of the republic Indonesia in the area pandemic corona virus (covid19). The rapid spread of the Covid-19 pandemic has caused disruption in the Indonesian education sector where around 45 million students are unable to continue their learning activities in school. The Ministry of Education and Culture and the Ministry of Religion need to consider implementing distance learning that is tailored to the different characteristics of regions in Indonesia. Distance learning adds barriers to students who already have difficulty accessing education, so the diversification of delivery media other than the internet needs to be considered. Options could be radio programming or using postal services for areas with low connectivity. This disruption to the traditional education system has disadvantaged students from underprivileged families and those in rural areas. These are students who, even under normal conditions, already face barriers to accessing education. Now they need to face additional barriers that arise from inequality in accessing technology infrastructure. The topography of Indonesia which consists of islands and mountains requires the provision of internet and cellular telecommunications. However, $4 \mathrm{G}$ coverage is mostly concentrated in Java Island because cellular telecommunication service providers, which are very market dependent, naturally prioritize urban areas over rural areas with smaller populations._unequal distribution of household internet in all existing areas. This gap in connectivity makes students who come from underprivileged families in rural areas outside Java at a very disadvantage. The sudden shift from face-to-face in the classroom to distance learning at home also shows the need for increased teacher capacity. Several studies have shown that the information, communication, and technology (ICT) competencies of Indonesian teachers are not evenly distributed across the region. Moreover, there are gaps in the quality of education across regions in Indonesia, especially between Java and outside Java, and between conditions. socio-economic. Unequal internet access, gaps in teacher qualifications, and quality of education, as well as a lack of ICT skills are vulnerabilities in distance learning initiatives in Indonesia.

\section{What are the efforts made Cyber education Management at the Defense University of the republic Indonesia in the area pandemic corona virus (covid19?}

The Ministry of Education and Culture began implementing initial efforts to prevent the spread of Covid-19 in schools by issuing Circular Number 3 of 2020 which outlines the practice of hygiene and sanitation in schools. The letter was issued two days before the World Health Organization (WHO) raised the status of Covid-19 to a global pandemic on March 11 (WHO, 2020). Due to the increasing spread, the Ministry of Education and Culture then decided to postpone all school activities and switch to online learning / distance learning at home through Circular Number 4 of 2020. The Ministry of Religion, which oversees 
Madrasahs, followed the call by issuing a Circular Number. B-686.1 / DJ.II / PP.00 / 03/2020. The Ministry of Education and Culture provides freedom for each school to choose their online learning platform (Kemendikbud, 2020a). However, to encourage knowledge sharing, the Ministry of Education and Culture provides a free online learning platform called "Rumah Belajar" and a platform for sharing between teachers called "Program Guru Berbagi". The "Rumah Belajar" provides teaching materials and communication features for its users, while the "Sharing Teacher Program" shares lesson plans (RPPs) with teachers across Indonesia. For areas where the internet connection is not very good, the government is working with TVRI, the state television station, to deliver the learning materials included in the Home Study program for several months (Beritasatu, 2020). The Covid-19 crisis also forced schools to reallocate larger budgets for distance learning expenditures. Ministry of Education and Culture Regulation Number 19 Year 2020 and Ministry of Religion Circular Letter number B-699 / Dt.1.1 / PP.03 / 03/2020 permit the use of BOS funds for the implementation of distance learning. This includes the cost of internet connection for students and teachers as well as the purchase of distance learning support devices. Through Presidential Regulation Number 54 of 2020, the Ministry of Education and Culture's budget is increased by $96 \%$, from IDR 36 trillion to IDR 70.7 trillion. The use of these large increases has not been described in detail, but many predict the funds will be used to support further distance learning initiatives. At the local government level, the DKI Jakarta Education Agency has issued a Circular regarding the arrangement of distance learning. The agency uses a special section on their website to share information about conducting distance learning. In addition, the page also provides a guide for using "Si Pintar by Simak", which is an integrated school information system for DKI Jakarta, where online learning modules can be accessed. The site also provides Google Classroom tutorials for teachers, a scheduled program for "Learning at Home" on TVRI, and a learning platform for vocational students called "WeKiddo SMK Bisa". The Jakarta local government also requires school principals to periodically report their distance learning progress. Local governments need to play a more active role in assisting schools without having to wait for initiatives from the central government. In addition to using existing School Operational Assistance (BOS) funds, district education offices must provide financial support and further technical guidance for schools in their area, such as access to recording studios and equipment, in order to accelerate the adoption of distance learning. Such guidance should also not forget private community schools. Indonesia needs to initiate a large-scale capacity building program in order to better implement distance learning across the region. Such efforts require a strategy and supervision of the use of BOS, increase the capacity of school principals and allow them to gain greater autonomy in schools, and equip teachers with technical and non-technical skills for distance learning. The Covid-19 crisis shows a large-scale need for state-private partnerships between relevant ministries (Ministry of Education and Culture and Ministry of Religion and Ministry of Information) and providers of telecommunications services and hardware. The partnership can use existing infrastructure to expand the implementation of distance learning across Indonesia. 


\section{Conclusion}

Based on the results of research and discussions regarding cyber education Management at the Defense University of the republic Indonesia in the area pandemic corona virus (covid19). The government and various parties have carried out an emergency response including by holding emergency schools for student university defense in the event of the corona virus pandemic. The psychological burden that hit children throughout Indonesia during the Covid-19 pandemic resulted in decreased motivation to learn. This condition requires special handling in order to create joyful learning activities. One form of special handling that is the focus of research and which will be discussed in this paper is learning activities that utilize electronic media. Produce graduates who are professional, innovative, civil-military leaders who have values of struggle and struggle that are able to synergize people's welfare needs with the interests of defense and state defense. Produce and contribute new knowledge in the fields of defense policy, management, strategy and technology both at the national and international levels.

Produce works of empirical knowledge, theories, concepts, methodologies, models, the latest work systems and defense capacity in the framework of the management of the national defense system. Produce a system of management and education administration according to quality standards, transparent, performance-based and the development of an academic culture. Generating benefits from partnerships and networks with various domestic and foreign agencies in supporting the Tridharma of Higher Education. The establishment of professional and competitive human resources (lecturers and educational staff) in the field of national defense and defense. The availability of educational facilities and infrastructure to support innovative and modern learning. 


\title{
SILNMEDUCATION
}

02-04 JULY, 2021

Oxford, United Kingdom

\section{References}

\author{
Books \\ Arsyad. (2009). Media Pembelajaran. Jakarta: Rajawali Pers. \\ Arsyad. 2007. Media Pembelajaran. Jakarta: PT. Raja Grafindo Persada. \\ Creswell, J. W. (2013). Qualitative inquiry and research design: Choosing among five \\ approaches (3rd ed.). Thousand Oaks, CA: Sage. \\ Daryanto. (2010). Belajar dan Mengajar. Bandung: C.V.Yrama Widya. \\ Daryanto. (2010). Media Pembelajaran. Yogyakarta: Gava Media. \\ Departemen Pendidikan Nasional. (2003). Undang-Undang No. 20 tahun 2003 tentang \\ Sistem \\ Pendidikan Nasional. Jakarta: Pusat Teknologi Informasi dan Komunikasi Pendidikan \\ Kementerian Pendidikan Nasional \\ Sadiman, Arief., dkk. (2007). Media Pendidikan Pengertian, Pengembangan dan \\ Pemanfaatannya. Jakarta: P. T. Raja Grafindo Persada.
}

\section{Edited Books}

Heinich, R., Molenda, M. dan Russell, J.D. (1982). Instructional Media and The New

Technology of

Instruction. New York: John Wiley \& Sons.

Murtini. (2010). "Meningkatkan Prestasi Belajar Matematika dengan Menggunakan Media VCD bagi Anak Tunarungu Kelas D-2 di SLB-B Gemolong tahun pelajaran 2009/2010". Skripsi. Solo: Fakultas Keguruan dan Ilmu Pendidikan Universitas Sebelas Maret Surakarta. Latuhelu, J.D. (1993). Media Pembelajaran dalam proses Belajar Mengajar Kini. Ujung Pandang:

Penerbit IKAPI Ujung Pandang.

\section{Journal Articles}

1976. The technology of foolishness. Pp. 69-81 in March and Olsen 1976.Find this resource:

Meade, J. E. 1970. The Theory of Indicative Planning. Manchester: Manchester University Press.Find this resource:

Olsen, J. P. 1972a. Public policymaking and theories of organizational choice. Scandinavian Political Studies, 7: 45-62.Find this resource:

—and Olsen, J. P. 1976. Ambiguity and Choice in Organizations. Bergen:

Universitetsfor-laget.Find this resource:

\section{Online Journals and websites}

https://covid19.go.id/p/berita/infografis-covid-19-13-september-2020 accessed on 14 September 2020 at $14.00 \mathrm{WIB}$

https:/ / www.oxfordhandbooks.com/view/10.1093/oxfordhb/9780199604456.001.0 001/oxfordhb-9780199604456-e-043 accessed on 14 September 2020 at 14.00 WIB (http://techonly13.wordpress.com accessed on 14 September 2020 at 14.00 WIB). https://bersamahadapikorona.kemdikbud.go.id/wpcontent/uploads/2020/08/SA LINAN_REVISI-SKB-4-MENTERI-PTM_AGUSTUS-2020.pdf $\quad$ accessed $\quad$ on 14 September 2020 at $14.00 \mathrm{WIB}$ 
http://vcdpembelajaran.com accessed on 14 September 2020 at 14.00 WIB

http://www.slideshare.net accessed on 14 September 2020 at 14.00 WIB

https://www.employment.govt.nz/leave-and-holidays/other-typesofleave/coronavirus workplace/covid-19-minimum-wage/ accessed on 14 September 2020 at 14.00 WIB There are as yet no vaccines or antiviral drugs to prevent or treat human coronavirus infections. Coronaviruses constitute the subfamily Orthocoronavirinae, in the family Coronaviridae, order Nidovirales, and realm Riboviria (de Groot RJ, Baker SC, Baric R, Enjuanes L, Gorbalenya AE, Holmes KV, Perlman S, Poon L, Rottier PJ, Talbot PJ, Woo PC, Ziebuhr J (2011). "Family Coronaviridae". In King AM, Lefkowitz E, Adams MJ, Carstens EB, International Committee on Taxonomy of Viruses, International Union of Microbiological Societies. Virology Division (eds.). Ninth Report of the International Committee on Taxonomy of Viruses. Oxford: Elsevier. pp. 806-28. doi:10.1016/B978-0-12384684-6.00068-9.ISBN 978-0-12-384684-6. S2CID 212719285)

(McIntosh K (1974). "Coronaviruses: A Comparative Review". In Arber W, Haas R, Henle $W$, Hofschneider PH, Jerne NK, Koldovský P, Koprowski H, Maalфe O, Rott $R$ (eds.). Current Topics in Microbiology and Immunology / Ergebnisse der Mikrobiologie und Immunitätsforschung. Current Topics in Microbiology and Immunology / Ergebnisse der Mikrobiologie und Immunitätsforschung. Berlin, Heidelberg: Springer. p. 87. doi:10.1007/978-3-642-65775-7_3. ISBN 978-3-642-65775-7) 